\title{
How Consumers Pay: Adoption and Use of Payments
}

\author{
Scott Schuh $^{1} \&$ Joanna Stavins ${ }^{2}$ \\ ${ }^{1}$ Federal Reserve Bank of Boston, 600 Atlantic Avenue, Boston, MA 02210, USA \\ ${ }^{2}$ Federal Reserve Bank of Boston, 600 Atlantic Avenue, Boston, MA 02210, USA \\ Correspondence: Joanna Stavins, Federal Reserve Bank of Boston, 600 Atlantic Avenue, Boston, MA 02210, USA. \\ Tel: 1-617-973-4217. Fax: 1-617-973-4218. E-mail: joanna.stavins@bos.frb.org \\ Received: February 14, 2013 \\ Accepted: March 2, 2013 \\ Online Published: March 7, 2013 \\ doi:10.5430/afr.v2n2p1 \\ URL: http://dx.doi.org/10.5430/afr.v2n2p1
}

\begin{abstract}
Using data from a nationally representative survey of U.S. consumers, we estimate Heckman two-stage regressions on the adoption and use of seven different payment instruments. We find that the characteristics of payment instruments are important in determining consumer payment behavior, even when controlling for demographic and financial attributes: difficulty to setup and keep records are especially important in explaining adoption of payments, while ease of use, cost and security are important in explaining which methods consumers use for transactions. For the first time, the number of payment methods adopted by consumers conditional on having access to a bank account is estimated, as the unbanked consumers' payment choices are much more limited than those of consumers with bank accounts. Because cost is found to significantly affect payment use, a potential increase in the cost of credit or debit cards following recent regulatory changes affecting those payment methods may lead to a reduction in U.S. consumers' reliance on payment cards for transactions.
\end{abstract}

Keywords: Consumer payments, Banking, Consumer surveys, Payment behavior

\section{JEL Classifications: E41, D14, D12}

\section{Introduction}

This paper addresses the question of what determines consumers' payment behavior. While previous literature has found that consumers' payment choice is affected by their demographic attributes (e.g., Bertaut and Haliassos 2006, Klee 2006, Mester 2003, Stavins 2001, Zinman 2009), characteristics of payment methods have also been shown to affect payment use. For example, Ching and Hayashi (2010) and Schuh and Stavins (2010) found that consumers' perceptions of payment attributes explain check use. Clearly, the perceptions of payment characteristics vary across individuals: one person may consider online banking convenient, while another may find it cumbersome. Measuring such attributes is important for estimating the demand for payments and for predicting future changes in the use of paper, card, and electronic payment methods.

This paper adds to the previous literature in several ways: (1) we use new survey data that have not been previously applied in the published literature, (2) we find that both adoption and use of payments depend on how consumers perceive payment attributes, even when controlling for numerous demographic and financial variables, and (3) we find that demographic variables significantly affect the number of payment methods a consumer adopts. The main findings are as follows:

- whether a payment method allows consumers to keep track of their transactions is a significant factor in a decision whether or not to adopt that payment method, especially for credit cards, debit cards, and online bill payments;

- difficulty of setting up a payment method can discourage consumers' adoption of that method, especially for debit cards and bank account number payments; 
- whether or not a payment method is considered easy to use has a major impact on how frequently it is used, conditional on having been adopted;

- older consumers adopt significantly fewer payment methods than younger consumers do.

To estimate both adoption and use of payments, we employ the two-step Heckman model approach. Adoption is the first stage in the payment behavior process, as it is a prerequisite to use, which is the second stage and requires that the payment method used had been previously adopted. We employ the 2008 Survey of Consumer Payment Choice - a nationally representative survey of U.S. consumers designed by the Federal Reserve Bank of Boston and administered by the RAND Corporation - to estimate adoption and use of seven different payment methods. We test for robustness of our methodology by using a variety of specifications. While the survey is similar in content to the 2006 survey used in Schuh and Stavins (2010), several important differences between the two surveys allow for better estimation in this study: The 2008 survey collected data on more payment instruments and includes ratings of payment instruments (payment characteristics) along several dimensions, both by adopters and by nonadopters of each payment method. In addition, a much more extensive set of questions allows gathering more information on the survey respondents.

We find that although demographic variables explain some of the variation in consumer payment behavior, the perceived characteristics of payments are significant for both the adoption and the use of payment instruments. Recentlyintroduced changes to debit card interchange fees (Note 1) can lead to an increase in the cost of debit cards to consumers. (Note 2) We find that both the adoption of debit cards and the use of debit cards - conditional on adoption - are sensitive to the cost of debit cards faced by consumers. This finding indicates that consumers may reduce their reliance on debit if banks raise the cost of setting up or using debit cards. We analyze how bank account adoption affects payment behavior, to show how unbanked consumers' payment choices are restricted compared to the choices faced by those with bank accounts.

The rest of the paper is organized as follows. Section 2 describes the survey data used in this paper. Section 3 shows the model used in the study. Section 4 analyzes the estimation results. Section 5 concludes.

\section{Data}

We use the 2008 Survey of Consumer Payment Choice (SCPC).The 2008 SCPC was conducted by the Consumer Payments Research Center (CPRC) at the Federal Reserve Bank of Boston. The survey was administered to a sample of 1,010 U.S. consumers by the RAND Corporation as a module of the American Life Panel. The survey asked all respondents about the characteristics of all payment methods, allowing us to estimate the effect of characteristics on payment adoption and on payment use for the whole sample, and not only for the users of a given payment method. The survey includes detailed information on holding (adoption) and use of nine payment instruments, including a breakdown of electronic bill payments into those conducted from a bank website and those initiated with a biller. We present some of the results of the survey most relevant to the adoption and use of payment instruments. (Note 3 )

\subsection{Payment Adoption}

The survey asked consumers about four paper instruments: cash, check, money orders, and traveler's checks; three payment cards: credit cards, debit cards, and prepaid cards (also called stored-value cards; and two types of online payments: online banking bill payment (OBBP) and bank account number payments (BAN). (Note 4)Online banking bill payments are payments made from a bank website when a consumer inputs information about the biller. In contrast, bank account number payments are made from the biller's website when a consumer inputs his bank account and bank routing numbers. Appendix Table A1 defines the payment instruments. The average consumer held 5.1 of the nine instruments and used 4.2 payment instruments in a typical month.However, consumers were very heterogeneous in the combination of payment instruments held. For additional information on payment adoption in the 2008 SCPC survey, see Mann (2011).

Table 1 shows the rates of adoption of payment instruments for the whole sample and broken down by demographic groups. We assume that a respondent has adopted cash if he responded "Yes" to the direct question about cash adoption, used cash for some payments, withdrew cash from an ATM or another source, or had cash at home or on person at the time of the survey.Overall, 98 percent of respondents were classified as cash adopters. 
Table 1. Rates of Adoption of Payment Instruments by US Consumers (percent)

\begin{tabular}{|c|c|c|c|c|c|c|c|c|}
\hline Categories & Variables & Cash* & Check & Credit & Debit & BAN & OBBP & Prepaid \\
\hline Total & & 98 & 91 & 78 & 80 & 73 & 52 & 17 \\
\hline \multirow{6}{*}{ Age } & Under 25 & 90 & 80 & 56 & 80 & 54 & 61 & 8 \\
\hline & $25-34$ & 98 & 84 & 68 & 83 & 79 & 69 & 16 \\
\hline & $35-44$ & 100 & 95 & 81 & 90 & 80 & 66 & 18 \\
\hline & $45-54$ & 100 & 93 & 81 & 79 & 72 & 39 & 20 \\
\hline & $55-64$ & 100 & 93 & 84 & 75 & 69 & 38 & 17 \\
\hline & 65 or Over & 100 & 100 & 95 & 72 & 81 & 40 & 22 \\
\hline \multirow{4}{*}{ Education } & HS or Less & 96 & 83 & 66 & 76 & 66 & 47 & 13 \\
\hline & Some College & 100 & 96 & 81 & 85 & 80 & 55 & 20 \\
\hline & College Degree & 100 & 99 & 94 & 84 & 75 & 58 & 19 \\
\hline & Post-Graduate School & 100 & 100 & 98 & 82 & 88 & 62 & 27 \\
\hline \multirow{4}{*}{ Marital Status } & Married & 100 & 98 & 87 & 86 & 81 & 59 & 17 \\
\hline & Separated & 90 & 79 & 70 & 67 & 67 & 42 & 15 \\
\hline & Widowed & 100 & 100 & 98 & 79 & 75 & 36 & 18 \\
\hline & Single & 100 & 79 & 53 & 75 & 53 & 45 & 22 \\
\hline Ethnicity & Latino & 100 & 94 & 82 & 88 & 77 & 75 & 7 \\
\hline \multirow{5}{*}{ Race } & White & 99 & 96 & 83 & 82 & 77 & 53 & 19 \\
\hline & Black & 88 & 67 & 50 & 68 & 54 & 38 & 8 \\
\hline & Asian & 100 & 100 & 100 & 85 & 83 & 62 & 29 \\
\hline & American Indian & 100 & 76 & 69 & 76 & 60 & 54 & 7 \\
\hline & Other & 100 & 76 & 55 & 72 & 61 & 64 & 11 \\
\hline \multirow{2}{*}{ Gender } & Male & 96 & 91 & 81 & 79 & 76 & 57 & 14 \\
\hline & Female & 100 & 91 & 75 & 81 & 71 & 48 & 20 \\
\hline \multirow{5}{*}{ Income } & $<\$ 25,000$ & 90 & 69 & 48 & 63 & 53 & 33 & 15 \\
\hline & $\$ 25,000-\$ 49,999$ & 100 & 94 & 75 & 85 & 76 & 58 & 15 \\
\hline & $\$ 50,000-\$ 74,999$ & 100 & 98 & 90 & 85 & 78 & 52 & 18 \\
\hline & $\$ 75,000-\$ 99,999$ & 100 & 98 & 92 & 79 & 81 & 51 & 17 \\
\hline & $>\$ 100,000$ & 100 & 100 & 96 & 88 & 81 & 69 & 26 \\
\hline \multirow{5}{*}{ Net Worth } & Less than $\$ 50,000$ & 94 & 83 & 59 & 81 & 69 & 48 & 17 \\
\hline & $\$ 50,000$ to $\$ 100,000$ & 100 & 93 & 80 & 86 & 76 & 47 & 11 \\
\hline & $\$ 100,000$ to $\$ 250,000$ & 100 & 92 & 82 & 82 & 76 & 58 & 16 \\
\hline & $\$ 250,000$ to $\$ 500,000$ & 100 & 99 & 94 & 84 & 81 & 64 & 21 \\
\hline & Greater than $\$ 500,000$ & 100 & 97 & 92 & 68 & 74 & 50 & 20 \\
\hline
\end{tabular}

Source: 2008 Survey of Consumer Payment Choice

Note: *A respondent "adopted" cash if he/she had cash on his/her person or property, or if he/she gets or uses cash at least once in a typical year

Anyone who had a checking account was classified as a check adopter. The rate of check adoption was almost as high as that for cash - over 90 percent of the sample had adopted checks.Check adoption was higher for older, higher income, or more educated respondents than for those who were younger, had lower incomes, or were less educated. It was lower for single or separated respondents than for those who were married or widowed, and it was lower for blacks than for white or Asian respondents.

The overall rate of credit card adoption was 78 percent. Similar to the adoption of checks, the rate of credit card adoption was higher for older, more educated, higher income, and higher wealth respondents; was much lower for blacks than for whites or Asians; and was lower for single or separated people than for those who were married or widowed. Men had a higher rate of credit card adoption than women did.

In contrast to earlier surveys (e.g., Survey of Consumer Finances), credit card adoption was below debit card adoption, which was 80 percent. However, the distribution within the sample differed substantially between the two payment methods. In contrast to credit cards, the adoption of debit cards was greater for the young than for the old, and was not higher for highly educated consumers (although it was lowest for those with the lowest level of education). Married respondents were more likely to have a debit card than those in any other category, especially those who were single, and blacks were less likely to adopt debit cards than were respondents of any other race. Even 
though debit adoption was lowest for those earning an annual income below $\$ 25,000$, there was no discernible difference among the remaining income groups.

The rate of adoption of bank account number payments (BAN) was 73 percent in this survey, compared with 49 percent in the 2006 version of the survey. (Note 5) The adoption of BAN did not exhibit strong demographic patterns, other than being lowest for the youngest, lowest-income, black, and least educated respondents. Because BAN is often used for housing-related payments, such as mortgage and utility payments, some of these differences are probably due to the lower rate of homeownership among those respondent groups. The adoption of online banking bill payment (OBBP) increased from 24 percent in 2006 to 52 percent in 2008 - the fastest growth of any payment method included in the survey. Similar to debit cards, the OBBP adoption rate was lower for older and less educated respondents, highest for married people, and lowest for blacks and those with annual income below $\$ 25,000$.

Approximately 6 percent of respondents did not have any bank accounts. Because most payment instruments require bank account adoption, the unbanked held — on average — slightly more than 1 payment method, compared with over 5 payment instruments per consumer with a bank account. Not surprisingly, unbanked consumers rely on cash much more heavily than bank account holders do: 76 percent of their transactions were conducted in cash, compared with 25 percent for consumers with a bank account.

\subsection{Payment Use}

Table 2 shows the use by adopters (intensive margin) of each payment method, measured as a share of all monthly payments. Note that the rows do not add to 100 , because each value is calculated as use among adopters of that payment method, not among all consumers, so the denominator varies across the payment instruments.

Table 2. Use of Payment Instruments by Adopters (percent share of monthly payments)

\begin{tabular}{|c|c|c|c|c|c|c|c|c|}
\hline Categories & Variables & Cash & Check & Credit & Debit & BAN & OBBP & Prepaid \\
\hline Total & & 24 & 16 & 25 & 35 & 10 & 6 & 3 \\
\hline \multirow{6}{*}{ Age } & Under 25 & 30 & 8 & 17 & 43 & 7 & 4 & 1 \\
\hline & $25-34$ & 24 & 11 & 22 & 41 & 11 & 6 & 6 \\
\hline & $35-44$ & 23 & 16 & 24 & 37 & 10 & 6 & 3 \\
\hline & $45-54$ & 27 & 18 & 23 & 32 & 11 & 6 & 3 \\
\hline & $55-64$ & 25 & 21 & 24 & 31 & 9 & 5 & 5 \\
\hline & 65 or Over & 18 & 19 & 36 & 22 & 12 & 10 & 2 \\
\hline \multirow{4}{*}{ Education } & HS or Less & 28 & 17 & 21 & 35 & 10 & 5 & 5 \\
\hline & Some College & 23 & 15 & 19 & 42 & 10 & 6 & 3 \\
\hline & College Degree & 21 & 15 & 31 & 29 & 11 & 7 & 2 \\
\hline & Post-Graduate School & 17 & 15 & 39 & 22 & 10 & 6 & 2 \\
\hline \multirow{4}{*}{ Marital Status } & Married & 21 & 16 & 27 & 34 & 10 & 6 & 2 \\
\hline & Separated & 25 & 20 & 17 & 37 & 11 & 8 & 7 \\
\hline & Widowed & 20 & 21 & 25 & 31 & 9 & 9 & 1 \\
\hline & Single & 37 & 11 & 26 & 36 & 12 & 4 & 4 \\
\hline Ethnicity & Latino & 25 & 15 & 18 & 37 & 8 & 5 & 2 \\
\hline \multirow{5}{*}{ Race } & White & 23 & 16 & 25 & 34 & 10 & 6 & 3 \\
\hline & Black & 29 & 14 & 18 & 35 & 13 & 6 & 10 \\
\hline & Asian & 20 & 14 & 40 & 20 & 16 & 6 & 3 \\
\hline & American Indian & 31 & 28 & 5 & 46 & 6 & 3 & 0 \\
\hline & Other & 28 & 15 & 16 & 45 & 10 & 6 & 0 \\
\hline \multirow{2}{*}{ Gender } & Male & 25 & 15 & 26 & 31 & 11 & 6 & 2 \\
\hline & Female & 23 & 17 & 24 & 37 & 9 & 6 & 4 \\
\hline \multirow{5}{*}{ Income } & $<\$ 25,000$ & 35 & 15 & 19 & 36 & 11 & 5 & 11 \\
\hline & $\$ 25,000-\$ 49,999$ & 25 & 17 & 22 & 38 & 9 & 5 & 2 \\
\hline & $\$ 50,000-\$ 74,999$ & 20 & 16 & 25 & 36 & 11 & 5 & 3 \\
\hline & $\$ 75,000$ - $\$ 99,999$ & 22 & 16 & 27 & 32 & 11 & 7 & 1 \\
\hline & $>\$ 100,000$ & 18 & 13 & 35 & 25 & 11 & 8 & 3 \\
\hline \multirow{5}{*}{ Net Worth } & Less than $\$ 50,000$ & 29 & 15 & 11 & 35 & 8 & 2 & 1 \\
\hline & $\$ 50,000$ to $\$ 100,000$ & 22 & 17 & 12 & 35 & 9 & 3 & 0 \\
\hline & $\$ 100,000$ to $\$ 250,000$ & 25 & 16 & 19 & 30 & 7 & 3 & 0 \\
\hline & $\$ 250,000$ to $\$ 500,000$ & 20 & 16 & 26 & 23 & 9 & 4 & 1 \\
\hline & Greater than $\$ 500,000$ & 20 & 20 & 35 & 13 & 8 & 3 & 0 \\
\hline
\end{tabular}

Source: 2008 Survey of Consumer Payment Choice 
For the whole sample, debit cards were the most intensively used payment method, with 35 percent of all transactions. Credit cards and cash were used almost equally, while checks-at 16 percent of all transactions - ranked fourth. Those numbers contrast with the 2006 survey findings, when checks constituted 38 percent of all transactions and were the most popular payment method, while cash was second with 30 percent of transactions.

Cash and debit card use was higher for younger, lower income, less educated and poorer respondents, and was highest for single people. In contrast, credit card use was higher for older, higher income, more educated and wealthier consumers. Check use was higher for older people, but did not show any other strong patterns. The use of BAN was fairly similar across the demographic cohorts, while the use of OBBP among adopters was moderately higher for older and higher-income respondents.

Figure 1 shows the use of payment methods by type of transaction. Most of the transactions took place at the point of sale, and the composition of payment methods used varied depending on the type: most of the point-of-sale transactions were conducted with cash or debit, while checks dominated bill payments.

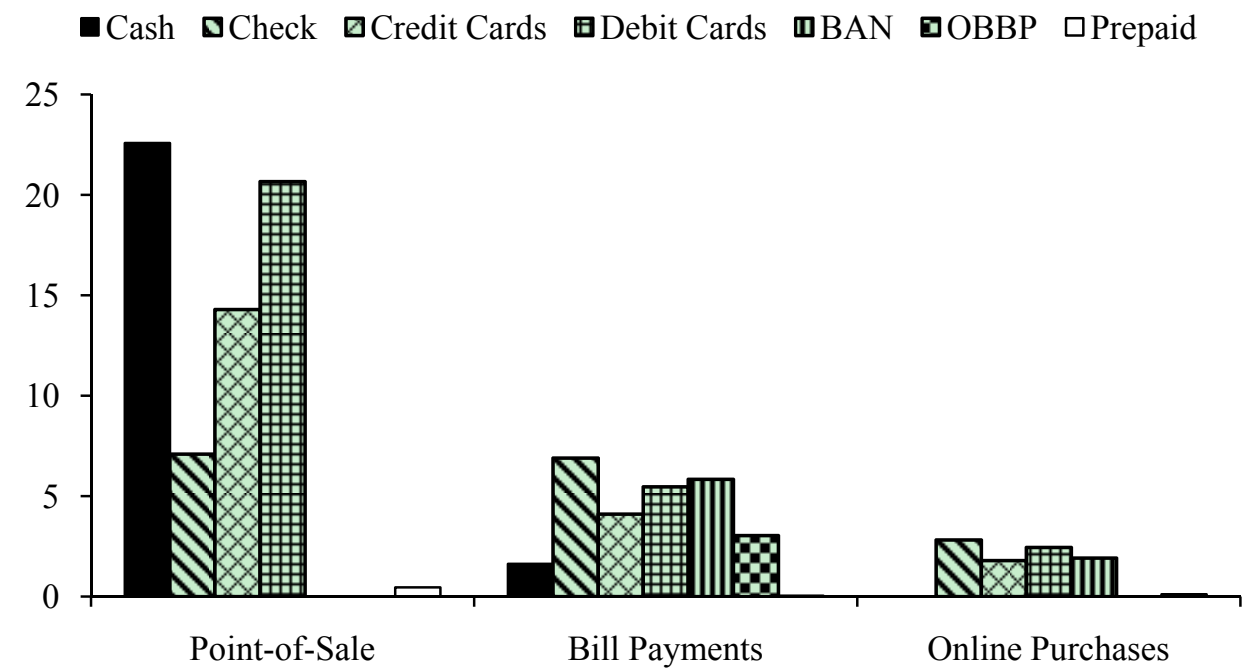

Source: 2008 Survey of Consumer Payment Choice

Figure 1. Share of Monthly Payments, by Payment Instrument and Type of Transaction

\subsection{Payment Characteristics}

Previous studies have found that demographic attributes are important determinants of consumer payment adoption (Bertaut and Haliassos 2006, Klee 2006, Mester 2003, Stavins 2001, Zinman 2009). However, demographics leave a substantial variation in payment behavior unexplained. Schuh and Stavins (2010) found that payment characteristics are significant in explaining consumer payment use. That study did not include payment characteristics in the adoption regressions, because the survey used in that paper asked only adopters of a given payment instrument about their perceived characteristics. In the survey used here, all respondents were asked about the characteristics of all payment instruments, regardless of whether they had adopted the payment in question. Therefore, we can include characteristics in the first-stage regressions.

The 2008 SCPC survey asked respondents to rate each payment method according to the following characteristics: cost (including fees and rewards), speed, setup, security, control over payment, record keeping, acceptance, and ease of use. The bottom panel of Appendix Table A1 shows how the characteristics were defined in the survey. Note that acceptance is the only characteristic that measures potential supply-side restrictions by payees.

Respondents assessed the characteristics on an absolute scale of 1 to 5 for each payment instrument, where 1 was the least desirable (for example, slowest or most expensive) and 5 was the most desirable (fastest or cheapest). Figure 2 shows the weighted means of the ratings of each payment method along each dimension, and a 95-percent confidence interval across respondents for each mean. One thing to note in the figure is that there is little variation across consumers in the way they assess payment characteristics, as exhibited by the short length of the 95-percent confidence bars around the means: the mean ratings ranged from 3.3 for prepaid to 3.8 for cash and debit cards, on a 1-to-5 scale. On the other hand, there is more variation across the characteristics, ranging from a 2.9 mean rating for security of payments to a 4.0 mean rating for acceptance. One characteristic that does vary across the payment instruments is cost: cash stands out as the least costly instrument, while credit cards are considered most expensive. Cash is also rated as the fastest and the easiest to set up, but also as least secure and worst for record keeping. 
Although not shown in the figure, adopters rated each payment method higher than did nonadopters, especially in terms of cost and setup of payments.

$*$ Cash $\bullet$ Check $\bullet$ Debit $\bullet$ Credit $\triangle$ Electronic deduction $\times$ Prepaid

- 95 percent confidence interval $\quad$ Average across all payment instruments
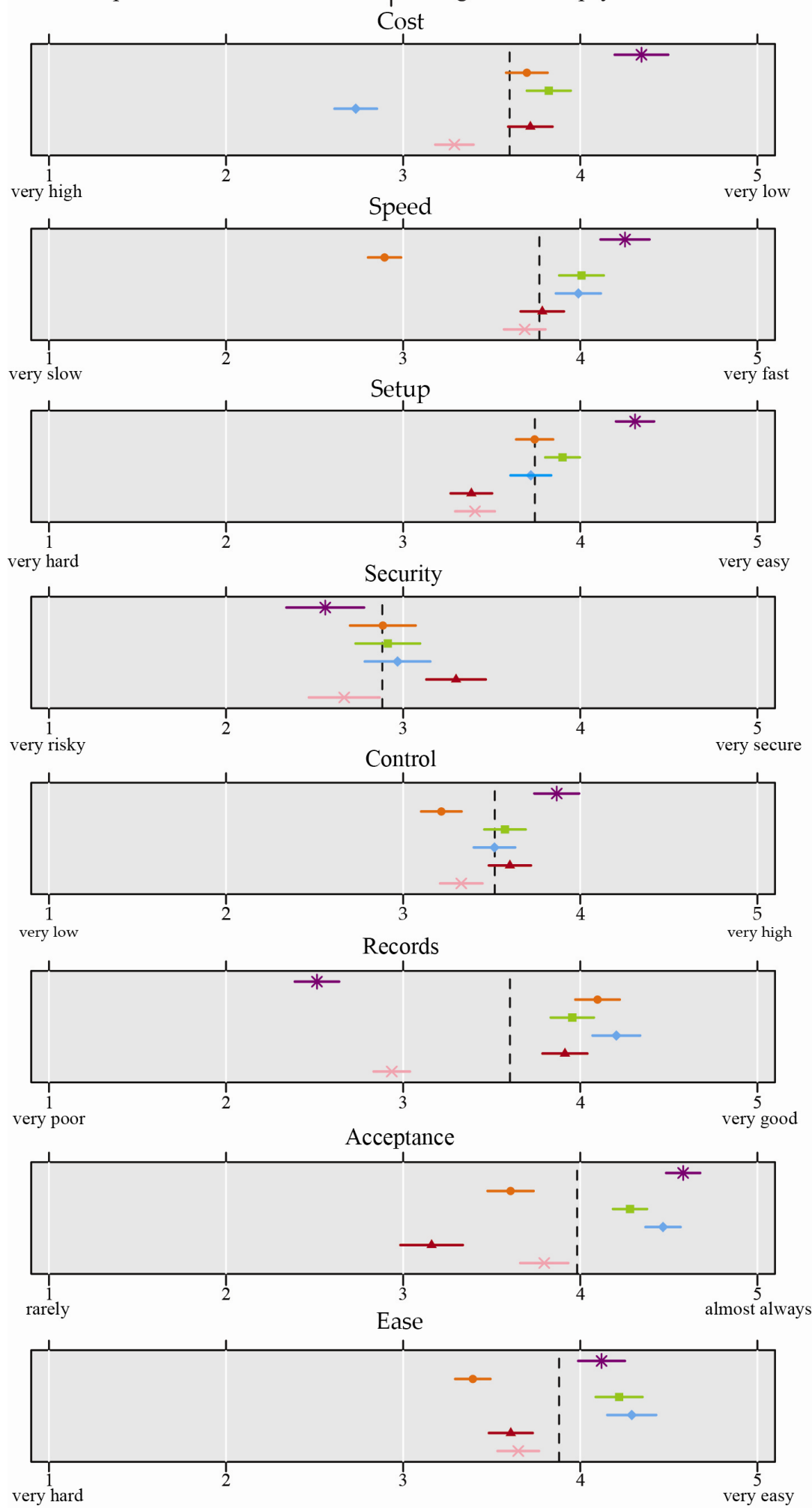

Source: 2008 Survey of Consumer Payment Choice

Figure 2. Weighted Means and Confidence Intervals of Payment Instruments by Characteristics 
Ratings by both adopters and nonadopters allow us to infer the major barriers preventing consumers from adoption. The biggest discrepancy in ratings between adopters and nonadopters was in cost, setup, and ease of use, suggesting that these were the main reasons consumers had not adopted certain payment instruments. (Note 6) Because the perceived payment characteristics varied even within each socio-demographic cohort, including the payment characteristics in the regressions of payment behavior helps to explain consumer decisions.

Although consumers rated each payment method according to each characteristic, including all those ratings in the regression would generate a large number of variables, and therefore a large number of coefficients to be estimated. Seven payment methods (cash, checks, credit cards, debit cards, BAN, OBBP, and prepaid) and eight characteristics (cost, speed, setup, security, control, records, acceptance, and ease of use) would generate 56 variables to be included in the regressions. Instead, we computed the average of each respondent's perceptions of each payment method relative to all the other methods. Following Schuh and Stavins (2010), we apply the following transformation:

$$
\operatorname{RCHAR}_{k i}\left(j, j^{\prime}\right) \equiv \log \left(\frac{C H A R_{k i j}}{C H A R_{k i j^{\prime}}}\right),
$$

where $k$ indexes the characteristics ( $k=$ cost, speed, setup, security, control over payment, record keeping, acceptance, and ease of use), $i$ indexes the consumer, $j$ is the payment instrument in question and $j^{\prime}$ is every other payment instrument besides $j$. For our baseline specification, we construct the average relative characteristic for each payment characteristic $k$ :

$$
\overline{\operatorname{RCHAR}}_{u}(j) \equiv \frac{1}{\tilde{J}_{i}} \sum_{j^{\prime} \neq j} R C H A R_{k i}\left(j, j^{\prime}\right),
$$

over all $\tilde{J}_{i}$ payment instruments for consumer $i$. For example, $\overline{R C H A R}_{i}(j)$ for $k=$ cost and $j=$ debit card is the average of the $\log$ ratios of debit card cost to the cost of each of the other payment instruments for consumer $i$. A high value of the variable would indicate that the consumer considers debit cards to be relatively less costly compared to the other payment methods (a higher rating indicates a better outcome). Note that we construct the characteristics relative to all payments, regardless of whether the consumer has adopted them.

Although transforming the rating variables that way by definition collapses some of the information, it actually creates new variables that are more informative than the numerical ratings provided in the survey. That is because a rating of 4 for the cost of debit cards, for example, cannot be easily interpreted, but a high rating relative to the ratings given to the other payment methods informs us whether the consumer considers debit cards to be relatively more or less costly.

Several other methods for including characteristics were tested.One of the specifications was using individual characteristics in the regressions (not averaged). However, that method severely limited the sample size used in the second-stage (use) regression and made the large number of coefficients on characteristics difficult to interpret. (Note 7)

\section{Model}

We expand on the previous consumer payment behavior literature in several ways. For the first time, we model the number of payment instruments adopted by a consumer conditional on bank account adoption. The number of payment options available to unbanked consumers is obviously very limited, as compared with the number available to those with bank accounts. Therefore, we estimate a two-step model: bank account adoption, and the number of payment instruments adopted conditional on bank account adoption. We then estimate a set of regressions for adoption and for use conditional on adoption, for each payment instrument separately. Unlike Schuh and Stavins (2010), we include payment characteristics in the adoption stage. We test various estimation techniques and model specifications.

\subsection{Number of payment instruments adopted}

The set of potential payment methods that a consumer can use depends on whether he has a checking account. In particular, checks, debit cards, bank account number deduction (BAN), and online banking bill payments (OBBP) can be used only by checking account holders.In contrast, cash, credit cards, and prepaid cards can be adopted and used regardless of whether the consumer has access to a bank account.Thus, whether or not a consumer has a bank account will determine his choice set and therefore precede his decision whether or not to adopt a specific payment method. We therefore model the number of payment methods adopted conditional on whether the consumer had adopted a checking account. 
We estimate the following equation for bank account adoption equation, as in Hogarth, et al. (2005):

$$
B_{i}=B\left(\overline{R C H A R}_{i}, D_{i}, Y_{i}\right),
$$

where $B_{i}$ is a dummy variable equal to 1 if consumer $i$ has adopted a checking account, $\overline{R C H A R}_{i}$ is a vector of consumer $i$ 's characteristics ratings of all the payment methods that require checking account adoption relative to consumer $i$ 's characteristics rating of cash (the characteristics variables are described in section 2.3 above), $D E M_{i}$ is a vector of consumer $i$ 's demographic variables that includes age, gender, race, education, marital status, a set of dummy variables for the geographic Census regions, and a dummy variable indicating whether consumer $i$ resides in an urban or rural area and whether he was born abroad, and $Y_{i}$ is a vector of consumer $i$ 's financial variables, including income, net worth, and employment status.

We estimate the number of payment methods adopted by consumer $i$, conditional on whether the consumer has adopted a checking account, as a two-stage Heckman model, with bank account adoption decision in equation (1) being the first-stage regression and the number of payment methods adopted being the second-stage regression:

$$
P_{i}=P\left(D E M_{i}, Y_{i}, M R_{i}^{-1}\right)
$$

where $P_{i}$ is the number of payment instruments adopted by consumer $i$; DEM $M_{i}$ is a vector of consumer $i$ 's demographic variables; $Y_{i}$ is a vector of consumer $i$ 's financial variables; and $M R_{i}^{-1}$ is the inverse Mills ratio from the first stage of the Heckman model. Note that the Heckman exclusion restriction is satisfied here, as a set of payment characteristic variables $\left(\overline{R C H A R}_{i}\right)$ is included in the first stage, but is excluded from the second stage.

\subsection{Payment Adoption}

We estimate both adoption and use of each payment instrument, where use is the share of transactions conducted with each payment instrument. In our two-stage model, consumers first adopt a portfolio of payment instruments, such as debit, credit, cash, and check. Thus adoption of payment methods is stage one and a prerequisite to use. Then, consumers choose how much to use each instrument.That is, consumers first pick adoption, and then use. We therefore separately estimate the effect of explanatory variables on adoption, and then on use, conditional on adoption.

We apply the Heckman (1976) selection model, which controls for potential selection bias in payment use. Because almost all respondents (98 percent) have adopted cash, we do not estimate the adoption regressions for cash.Instead, the cash use regression is estimated using OLS. To identify the Heckman 2-step model, exclusion restrictions are necessary.Namely, some right-hand-side variables from the adoption stage (step 1) should be excluded from the use stage (step 2). We discuss this further in the results section below. (Note 8)

In the first stage of the Heckman regressions, we estimate adoption of payment method $j$ by consumer $i$ using the following probit specification:

where

$$
A_{i j}=A\left(\overline{\operatorname{RCHAR}_{i j}}, D_{i} M_{i}, Y_{i}, Z_{i}\right)
$$

$$
A_{i j} \equiv\left\{\begin{array}{cc}
1 & \text { if consumer } i \text { has adopted payment instrument } j \\
0 & \text { otherwise },
\end{array}\right.
$$

$j=$ credit cards, debit cards, bank account number deduction (BAN), online banking bill payment (OBBP), or prepaid. As explained above, we do not estimate the first-stage regressions for cash. $\overline{R C H A R}_{i j}$ is a vector of relative characteristics of payment $j ; D E M_{i}$ is a vector of demographic variables that includes age, gender, race, education, marital status, a set of dummy variables for the geographic Census regions, and a dummy variable indicating whether consumer $i$ resides in an urban or rural area; $Y_{i}$ is a set of income, net worth, and employment status variables; and $Z_{i}$ is an additional set of control variables excluded from the use stage, namely number of children, homeownership, a dummy variable indicating whether the respondent had ever been bankrupt, and a dummy variable indicating whether the respondent tends to be late in paying his bills.

Most of the previous papers estimating the effects of individual consumers' socio-demographic attributes on payment adoption used data from the Surveys of Consumer Finances (SCF). (Note 9) Compared to the SCPC, the SCF has limited information on payment instrument adoption, even more limited data on the use of payment instruments, and no information on characteristics of payment instruments or consumers' attitudes regarding the 
instruments. Although demographic attributes have been found to influence consumer payment behavior, heterogeneity across consumers within demographic groups can be more important than heterogeneity across the demographic groups, and most of the cross-sectional variation in consumer payment use remains unexplained.Our analysis will indicate the degree to which including consumers' perceptions of the characteristics of the payment instruments reduces the unexplained variation in consumer payment behavior.

With the exception of Schuh and Stavins (2010), none of the prior studies in the literature had estimated adoption and use of payments with payment characteristics in a comprehensive way. This study improves upon the related empirical literature by using higher quality survey data and estimation method.

\subsection{Payments Use}

Following payment adoption, consumers decide how frequently to use the payment instruments they have adopted. Although in reality the adoption decision can be made in conjunction with the use decision-for example, a person can sign up for online banking and then immediately pay a bill online-adoption is a necessary prerequisite for use, and therefore in our model the two decisions are made sequentially.

We measure a consumer's use of a given payment instrument as a share of all transactions that the consumer conducted that month. The survey asks respondents about number of payments, but because a self-reported survey is likely to suffer from poor recall, shares are more likely to be unbiased, as long as respondents consistently underreport across all the payment instruments they use. We model the use of each payment instrument $j$ by consumer $i$ as follows:

$$
U_{i j}=U\left(\overline{R C H A R}_{i j}, D E M_{i}, Y_{i}, N U M_{0 i} \ldots N U M_{6 i}, M O_{i}, M R_{i}^{-1}\right) \text {, }
$$

where $_{U_{i j}} \equiv\left(n_{i j} / N_{i}\right)$ is the ratio of the number of payments consumer $i$ made using payment type $j$ to the total number of payments made by consumer $i$ in a month, and $N_{i} \equiv \sum_{j} n_{i j}$ is the total number of payments made by consumer $i$ using all payment instruments $j ; \overline{R C H A R}_{i j}$ is a vector of relative characteristics of payment $j$ by consumer $i$ as discussed below; $D E M_{i}$ is a vector of demographic variables. $Y_{i}$ is a set of income, net worth, employment status, and financial responsibility variables. $N U M_{0 i} \ldots N U M_{6 i}$ are dummy variables equal to 1 if consumer $i$ has $0, \ldots, 6$ other payment instruments. The $N U M$ dummy variables are included to control for the consumer's choice set, or for the number of payment instruments the consumer has adopted.Because we measure the use of each payment $j$ as a share of payments made using $j$, and not as the absolute number of payments, the shares are (by design) affected by the number of payment instruments adopted by the consumer. We include the $N U M$ variables to measure the relative importance of each payment instrument to the consumer, not its mathematical weight. $M O_{i}$ is a dummy variable indicating whether consumer $i$ has ever used money orders. We cannot measure the use of money orders the same way we measure the use of other payments, because the information in the survey is not sufficiently extensive.However, using money orders may provide information about consumers' preferences that are relevant in estimating the use of other instruments. $M R_{i}^{-1}$ is the inverse Mills Ratio from the first-stage Heckman probit model to control for simultaneity of the payment adoption and use decisions.

Our approach improves upon the existing empirical literature in several ways. Arango and Taylor (2009) estimated use as a function of some payment characteristics, but instead of the actual number of transactions conducted using each payment method, they employed a measure of frequency of use derived from qualitative survey responses, such as "rarely" or "never." In contrast, we use the number of transactions conducted using each payment method. Bounie and Francois (2006) estimated only the probability of using cash, check, or card for a single transaction, and not the number of transactions, and the diary data used in the estimation lacked any perceived payment characteristics. Borzekowski and Kiser (2007) and Borzekowski, Kiser, and Ahmed (2008) focus on a single payment instrument - debit cards. In contrast, we estimate shares of all transactions paid with each of the (up to) seven payment instruments that consumers have adopted.Klee (2008) used a choice of debit or check at checkout as a measure of use, but lacked data on the intensity of use and on demographic attributes of individual consumers. In Ching and Hayashi (2010), the only measure of use was a consumer's preferred payment instrument, and no estimation of either the extensive or intensive margins of payment use were included. Bolt, Humphrey, and Uittenbogaard (2008) estimated the use of electronic payments in Norway and the Netherlands as a function of relative prices to find that pricing has a small effect on payment choice. They therefore concluded that "convenience, safety, and other nonprice attributes of different payment instruments" play an important role in influencing payment behavior. However, their data did not allow them to measure such nonprice factors directly.

\section{Adoption and Use Results}

In this section, we present the regression results based on the models described above. Table 3 shows the summary statistics for the variables used in the regressions. 
Table 3. Summary Statistics of Regression Variables

\begin{tabular}{|c|c|c|c|c|c|}
\hline Categories & Variables & Mean & Std & Min & $\operatorname{Max}$ \\
\hline \multirow[t]{6}{*}{ Age } & Under 25 & 0.05 & 0.21 & 0 & 1 \\
\hline & 25 to 34 & 0.12 & 0.33 & 0 & 1 \\
\hline & 35 to 44 & 0.22 & 0.41 & 0 & 1 \\
\hline & 45 to 54 & 0.25 & 0.43 & 0 & 1 \\
\hline & 55 to 64 & 0.21 & 0.41 & 0 & 1 \\
\hline & Over 65 & 0.15 & 0.35 & 0 & 1 \\
\hline \multirow[t]{5}{*}{ Education } & Less Than High School & 0.02 & 0.14 & 0 & 1 \\
\hline & High School & 0.14 & 0.35 & 0 & 1 \\
\hline & Some College & 0.34 & 0.47 & 0 & 1 \\
\hline & College & 0.28 & 0.45 & 0 & 1 \\
\hline & Graduate School & 0.22 & 0.41 & 0 & 1 \\
\hline \multirow[t]{5}{*}{ Marital Status } & Married & 0.65 & 0.48 & 0 & 1 \\
\hline & Separated & 0.16 & 0.37 & 0 & 1 \\
\hline & Widowed & 0.04 & 0.20 & 0 & 1 \\
\hline & Single & 0.15 & 0.35 & 0 & 1 \\
\hline & Household Size & 2.79 & 1.50 & 1 & 10 \\
\hline Ethnicity & Latino & 0.04 & 0.20 & 0 & 1 \\
\hline \multirow[t]{4}{*}{ Race } & Black & 0.07 & 0.25 & 0 & 1 \\
\hline & Asian & 0.03 & 0.17 & 0 & 1 \\
\hline & White & 0.88 & 0.32 & 0 & 1 \\
\hline & American Indian/Other & 0.02 & 0.14 & 0 & 1 \\
\hline \multirow{2}{*}{ Gender } & Male & 0.44 & 0.50 & 0 & 1 \\
\hline & Female & 0.56 & 0.50 & 0 & 1 \\
\hline \multirow[t]{6}{*}{ Income } & Under $\$ 25,000$ & 0.11 & 0.32 & 0 & 1 \\
\hline & $\$ 25,000$ to $\$ 49,000$ & 0.22 & 0.42 & 0 & 1 \\
\hline & $\$ 50,000$ to $\$ 74,000$ & 0.21 & 0.41 & 0 & 1 \\
\hline & $\$ 75,000$ to $\$ 99,000$ & 0.21 & 0.41 & 0 & 1 \\
\hline & Over $\$ 100,000$ & 0.24 & 0.43 & 0 & 1 \\
\hline & Not Highest Income in Household & 0.33 & 0.47 & 0 & 1 \\
\hline \multirow[t]{6}{*}{ Net Worth } & Under $\$ 50,000$ & 0.20 & 0.40 & 0 & 1 \\
\hline & $\$ 50,000$ to $\$ 100,000$ & 0.11 & 0.31 & 0 & 1 \\
\hline & $\$ 100,000$ to $\$ 249,000$ & 0.22 & 0.41 & 0 & 1 \\
\hline & $\$ 250,00$ to $\$ 500,000$ & 0.19 & 0.39 & 0 & 1 \\
\hline & Over $\$ 500,000$ & 0.22 & 0.41 & 0 & 1 \\
\hline & Missing Net Worth & 0.07 & 0.25 & 0 & 1 \\
\hline \multirow[t]{4}{*}{ Employment Status } & Retired & 0.27 & 0.44 & 0 & 1 \\
\hline & Not Employed & 0.10 & 0.29 & 0 & 1 \\
\hline & Self-employed & 0.09 & 0.29 & 0 & 1 \\
\hline & Employed & 0.71 & 0.46 & 0 & 1 \\
\hline \multirow[t]{9}{*}{ Financial Responsibility } & Pays Bills & 3.88 & 1.43 & 1 & 5 \\
\hline & Shops & 3.83 & 1.24 & 1 & 5 \\
\hline & Born Abroad & 0.07 & 0.26 & 0 & 1 \\
\hline & Urban & 0.82 & 0.38 & 0 & 1 \\
\hline & Number of Children & 0.77 & 1.16 & 0 & 7 \\
\hline & Access to Internet & 0.97 & 0.18 & 0 & 1 \\
\hline & Homeowner & 0.81 & 0.39 & 0 & 1 \\
\hline & Ever Bankrupt & 0.20 & 0.40 & 0 & 1 \\
\hline & Paid Late & 0.46 & 0.50 & 0 & 1 \\
\hline
\end{tabular}

Source: 2008 Survey of Consumer Payment Choice 


\subsection{Adoption}

4.1.1 Checking account adoption and number of payment instruments

Because several payment instruments require that the consumer have access to a checking account, one can think of bank account adoption as the first step in several payment instruments' adoption. The purpose of this part of our estimation is to analyze to what extent the number of payments held by a consumer is affected by the consumer's demographic or financial attributes. Although we estimate bank account adoption as the first stage of this analysis, we focus on bank account adoption results to a greater extend below.

The results are in Table 4. The first column shows the results of the probit regression where the dependent variable is a dummy variable equal to 1 if a respondent adopted a checking account. Because the checking account adoption rate in the sample is very high (91.3 percent weighted), there is not enough variation in the control group of nonadopters to include a full set of explanatory variables. We find that low-income and black respondents are less likely than other consumers to have a checking account.

Table 4. Checking Account Adoption and Number of Instruments Adopted

\begin{tabular}{|c|c|c|c|c|}
\hline Categories & Variables & $\begin{array}{c}\text { Checking } \\
\text { Account } \\
\text { Adoption [a] } \\
\text { (Probit) }\end{array}$ & $\begin{array}{c}\text { Number of Payment } \\
\text { Instruments Adopted } \\
{[\mathrm{b}]} \\
\text { (OLS) }\end{array}$ & \\
\hline \multirow[t]{8}{*}{ Characteristics $^{\wedge}$} & Cost & -0.003 & & \\
\hline & Speed & 0.000 & & \\
\hline & Setup & 0.002 & & \\
\hline & Security & 0.000 & & \\
\hline & Control & 0.000 & & \\
\hline & Records & 0.004 & & \\
\hline & Acceptance & 0.002 & & \\
\hline & Ease & 0.006 & & \\
\hline \multirow{5}{*}{ Age (35-44 excluded) } & $<25$ & & 0.12 & \\
\hline & $25-34$ & & 0.07 & \\
\hline & $45-54$ & & -0.21 & ** \\
\hline & $55-64$ & & -0.45 & *** \\
\hline & $>65$ & & -0.37 & ** \\
\hline \multirow{4}{*}{ Education (College degree excluded) } & Some High School & & -0.93 & *** \\
\hline & High School & & -0.2 & \\
\hline & Some College/Assoc. Degree & & 0.01 & \\
\hline & At Least Some Post Grad. & & 0.19 & ${ }^{* *}$ \\
\hline \multirow{5}{*}{ Marital Status (Married excluded) } & Married & 0.013 & & \\
\hline & Divorced/Separated & & -0.09 & \\
\hline & Widowed & & -0.37 & ** \\
\hline & Single & & -0.29 & \\
\hline & Household Size & & -.01 & \\
\hline Ethnicity & Latino & & .46 & \\
\hline \multirow{3}{*}{ Race (White excluded) } & Black & -0.052 & .18 & \\
\hline & Asian & & .35 & \\
\hline & Other & -0.040 & -.18 & \\
\hline Gender & Male & & .08 & \\
\hline \multirow{4}{*}{ Income (50K-75K excluded) } & $<\$ 25,000$ & -0.041 & -.31 & \\
\hline & $\$ 25,000-\$ 49,999$ & & .02 & \\
\hline & $\$ 75000-\$ 99,999$ & & -.03 & \\
\hline & $>\$ 100,000$ & & .11 & \\
\hline
\end{tabular}

Continued on next page 
Table 4. Checking Account Adoption and Number of Instruments Adopted continued

\begin{tabular}{|c|c|c|c|c|}
\hline \multirow{2}{*}{ Income } & \multicolumn{2}{|l|}{ Not Highest in $\mathrm{HH}$} & \multirow[t]{2}{*}{-.20} & ** \\
\hline & 3rd or Lower in $\mathrm{HH}$ & -0.004 & & \\
\hline \multirow{5}{*}{ Net Worth (100K-250K excluded) } & $<\$ 50,000$ & & -.03 & \\
\hline & $\$ 50,000-\$ 99,999$ & & -.08 & \\
\hline & $\$ 250,000-\$ 499,999$ & & .05 & \\
\hline & $>\$ 500,000$ & & -.15 & \\
\hline & Missing Net Worth & & -.23 & \\
\hline \multirow{3}{*}{ Employment Status (Employed excluded } & Retired & & -.02 & \\
\hline & Not Employed & & -.10 & \\
\hline & Self-employed & & -.13 & \\
\hline \multirow{6}{*}{ Financial Responsibility } & Low Fin. Mgmt. & -0.015 & & \\
\hline & Paying Bills & & .02 & \\
\hline & Shopping & & .02 & \\
\hline & Born Abroad & -0.003 & -.11 & \\
\hline & Urban & & .12 & \\
\hline & Inverse Mill Ratio & & -.27 & \\
\hline \multirow[t]{4}{*}{ Census Regions Included? } & & No & Yes & \\
\hline & Number of Observations & 941 & 893 & \\
\hline & Psuedo R-square (CHAR) & 0.04 & & \\
\hline & Psuedo R-square (No CHAR) & 0.04 & & \\
\hline
\end{tabular}

Source: 2008 Survey of Consumer Payment Choice

[a] Marginal effects from thefirst stage of the Heckman two-step estimation.

[b] Shows the Heckman 2nd stage, which is conditional on checking account adoption.

${ }^{\wedge}$ Characteristics are the bank-related payment instruments (check, debit card, and BAN) relative to cash.

${ }^{*} \mathrm{p}<0.1,{ }^{* *} \mathrm{p}<0.05,{ }^{* * *} \mathrm{p}<0.01$

The last column in Table 4 shows the results of a $2^{\text {nd }}$ stage regression, where the dependent variable is the number of payment instruments adopted conditional on checking account adoption. (Note 10) Older, single, and less educated consumers adopted fewer payment instruments than younger, married or more educated consumers did. For example, consumers with a high school education had adopted 0.2 fewer payment instruments than consumers with a college degree. Neither income nor wealth is statistically significant. The inverse Mills ratio is not statistically significant either, showing no evidence of a selection bias.

\subsubsection{Characteristics}

For the other payment methods besides cash, we used the Heckman two-stage model to estimate adoption regressions from equation (3) and use regressions from equation (4). The rest of this section summarizes the first-stage results shown in Table 5. 
Table 5. Regression Results for Payment Instrument Adoption (Heckman 1st Stage)

\begin{tabular}{|c|c|c|c|c|c|c|c|}
\hline & & Checks & Credit & Debit & BAN & OBBP & Prepaid \\
\hline \multirow{8}{*}{ Characteristics } & Cost & 0.48 & 0.09 & $0.45^{* *}$ & $0.30^{*}$ & 0.14 & 0.19 \\
\hline & Speed & 0.12 & 0.25 & $0.55^{*}$ & -0.01 & -0.13 & -0.04 \\
\hline & Setup & 0.06 & 0.39 & $1.12^{* * *}$ & $0.62^{* * *}$ & 0.22 & 0.15 \\
\hline & Security & 0.32 & 0.07 & 0.06 & $0.41^{* * *}$ & $0.22^{* *}$ & 0.01 \\
\hline & Control & 0.14 & $0.42^{*}$ & $0.34^{*}$ & -0.07 & 0.08 & 0.22 \\
\hline & Records & -0.06 & $1.04^{* * *}$ & $0.92^{* * *}$ & $0.31^{*}$ & $0.46^{* * *}$ & -0.07 \\
\hline & Acceptance & $-0.54^{*}$ & -0.29 & -0.20 & 0.02 & -0.09 & $0.74^{* * *}$ \\
\hline & Ease & -0.01 & $0.96^{* * *}$ & $0.51^{*}$ & 0.27 & 0.11 & 0.33 \\
\hline \multirow{5}{*}{ Age } & Under 25 & $-0.97^{* *}$ & -0.24 & 0.67 & 0.07 & 0.39 & 0.26 \\
\hline & 25 to 34 & -0.21 & -0.22 & -0.20 & $0.38^{*}$ & 0.01 & -0.05 \\
\hline & 45 to 54 & $0.47^{*}$ & 0.27 & $-0.42^{*}$ & 0.09 & $-0.38^{* * *}$ & 0.05 \\
\hline & 55 to 64 & 0.11 & 0.07 & $-0.45^{*}$ & -0.11 & $-0.55^{* * *}$ & 0.19 \\
\hline & Over 65 & 0.19 & 0.08 & -0.27 & 0.22 & $-0.67^{* * *}$ & 0.26 \\
\hline \multirow{4}{*}{ Education } & Less Than High School & $-1.62^{* * * *}$ & $-1.58^{* * * *}$ & $-1.46^{* * *}$ & $-1.08^{* *}$ & $-1.03^{* *}$ & \\
\hline & High School & -0.41 & -0.36 & -0.15 & 0.02 & -0.06 & 0.05 \\
\hline & Some College & 0.27 & -0.20 & -0.10 & 0.17 & 0.06 & -0.04 \\
\hline & Graduate School & $0.57^{*}$ & 0.31 & 0.08 & $0.35^{* *}$ & 0.07 & $0.31^{* *}$ \\
\hline \multirow{4}{*}{ Marital Status } & Separated & $-0.65^{* *}$ & -0.19 & -0.08 & $-0.39^{* *}$ & -0.04 & -0.29 \\
\hline & Widowed & 0.00 & 0.12 & -0.38 & $-0.68^{* *}$ & -0.31 & -0.47 \\
\hline & Single & -0.08 & $-0.63^{* * *}$ & -0.21 & $-0.42^{* *}$ & $-0.30^{*}$ & -0.08 \\
\hline & Household Size & $-0.24^{* * * 1}$ & $-0.24^{* * * *}$ & -0.01 & -0.06 & -0.09 & -0.11 \\
\hline Ethnicity & Latino & $2.45^{* * * 4}$ & $1.43^{* * *}$ & 0.39 & $0.83^{* *}$ & $0.73^{* *}$ & -0.28 \\
\hline \multirow{3}{*}{ Race } & Black & $-0.72^{* *}$ & -0.01 & -0.32 & -0.05 & -0.18 & $-0.59^{* *}$ \\
\hline & Asian & 0.04 & & 0.17 & 0.45 & $0.74^{* *}$ & -0.12 \\
\hline & American Indian/Other & $-2.14^{* * *}$ & $-1.23^{* *}$ & -0.65 & $-1.07^{* *}$ & -0.03 & -0.24 \\
\hline Gender & Male & $-0.50^{* *}$ & 0.09 & 0.06 & 0.09 & 0.14 & -0.16 \\
\hline \multirow{5}{*}{ Income } & Under $\$ 25,000$ & $-0.96^{* * *}$ & $-0.52^{* *}$ & $-0.44^{*}$ & $-0.60^{* * *}$ & -0.26 & 0.05 \\
\hline & $\$ 25,000$ to $\$ 49,000$ & -0.23 & 0.06 & 0.04 & -0.15 & 0.24 & 0.11 \\
\hline & $\$ 75,000$ to $\$ 99,000$ & -0.22 & 0.11 & 0.02 & 0.00 & 0.04 & 0.08 \\
\hline & Over $\$ 100,000$ & $-0.51^{*}$ & 0.23 & 0.24 & -0.01 & 0.24 & 0.12 \\
\hline & $\begin{array}{l}\text { Not Highest Income in } \\
\text { Household }\end{array}$ & -0.02 & -0.03 & -0.08 & -0.06 & $-0.28^{* *}$ & -0.07 \\
\hline \multirow{5}{*}{ Net Worth } & Under $\$ 50,000$ & 0.39 & -0.32 & 0.08 & -0.16 & 0.01 & -0.01 \\
\hline & $\$ 50,000$ to $\$ 100,000$ & 0.12 & -0.03 & 0.10 & 0.08 & -0.17 & $-0.46^{* *}$ \\
\hline & $\$ 250,00$ to $\$ 500,000$ & -0.50 & -0.11 & -0.05 & -0.10 & $0.30^{* *}$ & 0.01 \\
\hline & Over $\$ 500,000$ & 0.31 & 0.15 & $-0.52^{* * *}$ & -0.28 & 0.15 & 0.05 \\
\hline & Missing Net Worth & 0.43 & -0.28 & $-0.66^{* *}$ & -0.46 & -0.07 & $0.44^{*}$ \\
\hline \multirow{3}{*}{ Employment } & Retired & 0.12 & 0.02 & 0.14 & 0.01 & 0.10 & -0.09 \\
\hline & Not Employed & -0.13 & -0.41 & -0.15 & 0.06 & -0.07 & -0.34 \\
\hline & Self-employed & 0.06 & -0.34 & -0.16 & 0.05 & 0.08 & -0.30 \\
\hline Financial & Pays Bills & 0.18 & 0.12 & 0.09 & 0.10 & -0.07 & -0.05 \\
\hline \multirow[t]{11}{*}{ Responsibility } & Shops & -0.10 & -0.07 & -0.04 & 0.06 & 0.07 & 0.06 \\
\hline & Born Abroad & 0.11 & 1.04 & -0.48 & -0.01 & -0.34 & -0.11 \\
\hline & Urban & -0.18 & 0.30 & 0.15 & 0.05 & 0.07 & $0.28^{*}$ \\
\hline & Number of Children & 0.21 & 0.15 & 0.16 & 0.10 & $0.14^{*}$ & $0.17^{* *}$ \\
\hline & Access to Internet at Home & 0.89 & 0.51 & 0.38 & 0.39 & $0.58^{* * *}$ & -0.17 \\
\hline & Owns Home & 0.79 & 0.11 & 0.35 & -0.09 & 0.12 & -0.17 \\
\hline & Ever Had Bankruptcy & -0.34 & -0.68 & 0.30 & 0.17 & -0.07 & 0.10 \\
\hline & Paid Late & 0.30 & 0.10 & 0.25 & 0.23 & 0.14 & 0.04 \\
\hline & Observations & 866 & 882 & 901 & 904 & 871 & 891 \\
\hline & Psuedo R-square (CHAR) & 0.42 & 0.43 & 0.31 & 0.17 & 0.12 & 0.11 \\
\hline & Psuedo R-square (No CHAR) & 0.40 & 0.38 & 0.18 & 0.10 & 0.10 & 0.07 \\
\hline
\end{tabular}

Source: 2008 Survey of Consumer Payment Choice

${ }^{*} \mathrm{p}<0.1,{ }^{* *} \mathrm{p}<0.05,{ }^{* * *} \mathrm{p}<0.01$ 
Several of the characteristics were significant in the adoption regressions. (Note 11) Credit card adoption was affected by record keeping, ease of use, and control over payment timing. In debit card adoption, most of the characteristics were found to be significant, especially setup and record keeping. In the BAN regression, coefficients on setup and security were most significant and of largest magnitude, but record keeping and cost were also significant. In the OBBP adoption, record keeping and security were found significant.Only acceptance was significant in the prepaid adoption.

The results show that the difficulty of setup, record keeping, security, and ease of use were the most important factors in consumers' decision whether or not to adopt payment methods. A significant positive coefficient on security for any payment method indicates that people who see this method as relatively more secure are more likely to adopt it (and conversely - those who see the payment method as relatively less secure are less likely to adopt it). Thus, consumers' different perceptions of security of providing online information are important determinants of their adoption of bank account number payments and online banking bill payments.

Below we compare these results to the effect of characteristics in the use regressions.

\subsubsection{Demographic and financial effects}

The SCPC includes a wide array of demographic and financial variables. In this section, we summarize the estimated effects of those explanatory variables on the adoption of payment instruments. In contrast to Schuh and Stavins (2010), this paper includes characteristics of payments in the adoption regressions. Therefore the coefficients on demographic and financial variables pick up the intended effects and not the effects omitted variables on the probability of adoption. Most notably, fewer demographic or financial variables are significant in this paper than in Schuh and Stavins (2010), probably because some of the coefficients in that paper were picking up the effects now measured with the characteristics. At the bottom of the table we show pseudo $R^{2}$ with and without the characteristics variables. In all the regressions, the pseudo $R^{2}$ increased when characteristics were included, so including the characteristics has improved the fit.

Age is significant in the adoption of debit cards and OBBP: older consumers were significantly less likely to adopt these payment methods. In contrast, the youngest consumers were the least likely to adopt checks. There were no significant effects of age on adoption of other payments. Consumers with less than a high school diploma were much less likely to adopt any payment method (the variable is not included in the prepaid regression because so few people in that education group in the survey used prepaid cards). Those with post-graduate education were more likely to adopt checks, BAN, and prepaid, but other education coefficients are not statistically significant. Income seems to have had little effect on adoption, except for consumers in the lowest income cohort (below $\$ 25 \mathrm{~K}$ ), who were less likely to adopt almost any payment method. Respondents with the highest net worth (above $\$ 500 \mathrm{~K}$ ) were less likely to adopt debit cards.Homeowners were more likely to have checks or debit cards, while those who had filed for bankruptcy in the past were less likely to have credit cards, probably because of supply-side restrictions. Interestingly, those consumers who self-reported as forgetting to pay their bills on time were more likely to adopt checks, debit cards, and BAN, but there was no significant effect of that variable on credit card adoption.

\subsection{Use (share) results}

The survey asked respondents for the number of payments they make in a typical month. Because respondents might underestimate the exact number of transactions they conduct in a typical month, we measure payment use in terms of shares of the total number of payments that are conducted with a given payment instrument. As long as the respondents proportionally underestimate each payment method, the shares will give us unbiased measures of their payment use. Note that check use also includes money orders, as the survey asked about joint check and money order use. However, the second-stage Heckman regressions were estimated for check adopters only, and the incidence of money order use among check adopters was low (11 percent of check adopters had used money orders). (Note 12)

\subsubsection{Characteristics}

Several of the characteristics variables were highly significant in the use regressions (Table 6). Consumers' perception of ease of use affects the use of all payment methods, with the exception of prepaid cards. The effect is particularly strong for the use of credit and debit cards. The coefficients are all positive, as expected, meaning that consumers who perceive a payment method as easy to use conduct a significantly higher share of their transactions with that payment method. Cost is found to affect significantly only credit and debit use, and the coefficients are large in magnitude. A positive coefficient on a characteristic variable means that consumers either use a given payment method more frequently because they consider it superior based on that characteristic, or-on the contrary - they use a given payment method less frequently because they consider it inferior. Thus a positive and significant coefficient on the speed of checks likely means that consumers use checks less frequently because they consider them slow. 
Table 6. Regression Results for Payment Instrument Use (Heckman 2nd Stage)

\begin{tabular}{|c|c|c|c|c|c|c|c|c|}
\hline & & Cash & Checks & Credit & Debit & BAN & 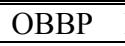 & Prepaid \\
\hline \multirow{6}{*}{ Characteristics } & Cost & 0.01 & 0.01 & $0.10^{* * *}$ & $0.11^{* * * *}$ & 0.01 & 0.00 & 0.02 \\
\hline & Speed & 0.03 & $0.03^{* *}$ & 0.00 & $0.08^{*}$ & -0.01 & -0.02 & $0.04^{* *}$ \\
\hline & Security & $0.02^{* *}$ & $0.03^{* *}$ & 0.00 & $0.06^{* *}$ & -0.01 & $-0.03^{* * *}$ & $0.02^{* *}$ \\
\hline & Control & $0.02^{*}$ & 0.01 & 0.01 & 0.03 & 0.01 & 0.01 & 0.00 \\
\hline & Records & 0.01 & -0.02 & $0.14^{* * *}$ & $-0.12^{* * *}$ & 0.01 & 0.00 & $0.02^{*}$ \\
\hline & Ease & $0.05^{* * *}$ & $0.06^{* * *}$ & $0.09^{* *}$ & $0.13^{* * *}$ & $0.04^{* * *}$ & $0.02^{*}$ & 0.00 \\
\hline \multirow{5}{*}{ Age } & Under 25 & -0.02 & -0.01 & -0.08 & $0.11^{* *}$ & 0.00 & -0.01 & $-0.08^{* * *}$ \\
\hline & 25 to 34 & $-0.05^{* *}$ & 0.01 & -0.03 & 0.04 & 0.00 & 0.02 & 0.02 \\
\hline & 45 to 54 & -0.01 & 0.02 & -0.02 & 0.03 & 0.00 & 0.01 & 0.00 \\
\hline & 55 to 64 & -0.02 & $0.06^{* * *}$ & -0.03 & $0.05^{*}$ & 0.00 & 0.00 & 0.01 \\
\hline & Over 65 & $-0.04^{*}$ & $0.04^{*}$ & 0.03 & -0.01 & 0.01 & 0.01 & 0.01 \\
\hline \multirow{4}{*}{ Education } & Less Than High School & 0.04 & -0.09 & -0.18 & 0.07 & -0.06 & -0.06 & \\
\hline & High School & 0.00 & 0.02 & -0.04 & 0.02 & 0.01 & 0.00 & 0.02 \\
\hline & Some College & 0.02 & 0.00 & $-0.05^{* *}$ & $0.05^{* *}$ & -0.01 & -0.01 & 0.00 \\
\hline & Graduate School & 0.00 & -0.01 & $0.04^{*}$ & -0.04 & -0.02 & $-0.02^{*}$ & 0.00 \\
\hline \multirow{4}{*}{ Marital Status } & Separated & 0.03 & 0.01 & -0.04 & 0.03 & 0.01 & 0.00 & 0.02 \\
\hline & Widowed & 0.04 & -0.01 & -0.04 & 0.03 & 0.01 & -0.01 & -0.02 \\
\hline & Single & $0.03^{*}$ & -0.02 & 0.02 & 0.00 & $0.04^{* * *}$ & * 0.01 & 0.00 \\
\hline & Household Size & 0.00 & $0.01^{*}$ & $-0.02^{* *}$ & 0.01 & $0.01^{* * *}$ & 0.00 & 0.01 \\
\hline Ethnicity & Latino & 0.03 & -0.04 & 0.01 & -0.05 & 0.01 & 0.01 & -0.03 \\
\hline \multirow{3}{*}{ Race } & Black & -0.01 & 0.00 & -0.05 & 0.00 & 0.01 & -0.01 & $0.08^{* *}$ \\
\hline & Asian & $-0.08^{* *}$ & -0.02 & $0.12^{* *}$ & $-0.14^{* *}$ & $0.08^{* * *}$ & -0.01 & 0.00 \\
\hline & American Indian/Other & -0.07 & 0.06 & 0.00 & 0.06 & 0.03 & 0.03 & 0.03 \\
\hline Gender & Male & $0.05^{* * *}$ & -0.01 & 0.00 & $-0.06^{* * *}$ & 0.01 & $-0.02^{*}$ & -0.01 \\
\hline \multirow{5}{*}{ Income } & Under $\$ 25,000$ & $0.06^{* *}$ & -0.01 & -0.03 & -0.03 & 0.00 & -0.01 & $0.07^{* * *}$ \\
\hline & $\$ 25,000$ to $\$ 49,000$ & $0.04^{* *}$ & 0.02 & -0.02 & -0.02 & $-0.02^{*}$ & -0.02 & -0.02 \\
\hline & $\$ 75,000$ to $\$ 99,000$ & -0.01 & 0.01 & -0.01 & -0.01 & 0.00 & 0.00 & -0.02 \\
\hline & Over $\$ 100,000$ & -0.02 & 0.00 & 0.03 & $-0.05^{*}$ & 0.00 & 0.02 & 0.00 \\
\hline & $\begin{array}{l}\text { Not Highest Income in } \\
\text { Household }\end{array}$ & 0.02 & -0.01 & -0.01 & 0.00 & 0.00 & -0.02 & 0.01 \\
\hline \multirow{5}{*}{ Net Worth } & Under $\$ 50,000$ & 0.01 & 0.01 & $-0.05^{*}$ & 0.03 & 0.01 & 0.02 & 0.01 \\
\hline & $\$ 50,000$ to $\$ 100,000$ & -0.03 & 0.00 & -0.04 & 0.03 & $0.03^{* *}$ & 0.01 & -0.02 \\
\hline & $\$ 250,00$ to $\$ 500,000$ & 0.01 & 0.00 & -0.01 & -0.02 & $0.02^{* *}$ & 0.01 & -0.01 \\
\hline & Over $\$ 500,000$ & 0.01 & 0.01 & $0.06^{* *}$ & $-0.07^{* *}$ & 0.01 & 0.00 & 0.00 \\
\hline & Missing Net Worth & -0.01 & -0.03 & $0.08^{*}$ & $0.14^{* * *}$ & -0.02 & -0.02 & -0.01 \\
\hline \multirow{3}{*}{$\begin{array}{c}\text { Employment } \\
\text { Status }\end{array}$} & Retired & -0.01 & $-0.03^{*}$ & 0.04 & -0.04 & 0.00 & $0.03^{*}$ & 0.00 \\
\hline & Not Employed & $-0.05^{* *}$ & 0.03 & 0.01 & 0.01 & 0.00 & 0.01 & 0.02 \\
\hline & Self-employed & -0.02 & -0.02 & 0.04 & 0.02 & -0.01 & 0.02 & 0.00 \\
\hline \multirow{5}{*}{$\begin{array}{c}\text { Financial } \\
\text { Responsibility } \\
\end{array}$} & Pays Bills & $-0.02^{* * *}$ & -0.01 & 0.01 & -0.01 & 0.00 & $0.01^{* *}$ & 0.00 \\
\hline & Shops & 0.00 & $0.01^{*}$ & -0.01 & 0.01 & 0.00 & -0.01 & -0.01 \\
\hline & Born Abroad & 0.03 & -0.02 & 0.05 & 0.01 & $-0.03^{* *}$ & 0.01 & 0.02 \\
\hline & Urban & 0.02 & -0.01 & -0.03 & 0.00 & -0.01 & 0.02 & $0.03^{*}$ \\
\hline & Zero & $0.36^{* * *}$ & & & & & & \\
\hline \multirow{11}{*}{$\begin{array}{l}\text { Number of Other } \\
\text { Payment } \\
\text { Instruments } \\
\text { Adopted }\end{array}$} & One & $0.51^{* * *}$ & -0.02 & & & 0.14 & & $-0.17^{* * *}$ \\
\hline & Two & $0.06^{* *}$ & $0.12^{* * *}$ & $-0.10^{* *}$ & -0.06 & $-0.10^{*}$ & -0.01 & 0.01 \\
\hline & Four & -0.02 & $-0.06^{* * *}$ & -0.03 & -0.03 & -0.01 & 0.02 & $-0.06^{* * *}$ \\
\hline & Five & $-0.07^{* * *}$ & $-0.09^{* * *}$ & $-0.05^{*}$ & -0.03 & 0.01 & 0.01 & $-0.06^{* * *}$ \\
\hline & Six & $-0.07^{* * *}$ & $-0.14^{* * *}$ & 0.00 & -0.04 & -0.01 & -0.01 & $-0.05^{* *}$ \\
\hline & Used Money Order & $0.05^{* * *}$ & 0.03 & -0.03 & -0.02 & $-0.03^{* *}$ & $-0.03^{* *}$ & 0.01 \\
\hline & Bought SVC & & & & & & & $0.04^{* * *}$ \\
\hline & Inverse Mills Ratio & & $-0.08^{* *}$ & 0.03 & $-0.18^{* * *}$ & -0.01 & -0.02 & -0.02 \\
\hline & Number of Observations & 915 & 823 & 787 & 740 & 692 & 451 & 186 \\
\hline & Adjusted R-square (CHAR) & 0.31 & 0.24 & 0.23 & 0.26 & 0.05 & 0.04 & 0.34 \\
\hline & Adjusted R-square (No CHAR) & 0.29 & 0.20 & 0.16 & 0.18 & 0.03 & 0.03 & 0.29 \\
\hline
\end{tabular}

Source: 2008 Survey of Consumer Payment Choice

${ }^{*} \mathrm{p}<0.1,{ }^{* *} \mathrm{p}<0.05,{ }^{* * *} \mathrm{p}<0.01$ 
Compared with earlier studies, security was more important to consumers in the 2008 survey. Surprisingly, the coefficient on security is negative and significant for online bill payments. The effect of record keeping was strong for credit and debit cards, although surprisingly the coefficient is negative for debit cards, possibly showing that consumers use debit cards despite considering debit as poor record-keeping instruments. Speed was significant for check use, and that characteristic seems to be one of the main reasons why consumers use fewer checks: checks received the lowest rating for speed, and speed (along with security) received the lowest rating of all the check characteristics. Speed also significantly affected debit and prepaid use. Jointly, characteristics influenced payment use strongly, as indicated by the fact that adjusted $R^{2}$ is higher in every regression with characteristics than without characteristics.

\subsubsection{Demographic and financial effects}

The effect of demographic attributes on payment use is consistent with previous findings.Older people used more checks, while younger people used more debit cards. More-educated consumers used more credit cards, but less OBBP. Cash share was 5 percentage points higher for men than for women, while debit card share was 6 percentage points lower. Asian respondents used credit cards and BAN relatively more intensively, but cash and debit cards less intensively than other consumers. Lower income was associated with higher use of cash, but in the case of debit and credit cards, net worth was more important than income: highest net worth consumers used credit cards more intensively, and debit cards less intensively than the rest of the sample. Those who were not employed had a 5 percentage points lower share of cash, while retired respondents (controlling for age) had a 3 percentage points higher share of online banking bill payments. Having financial responsibility for paying bills did not significantly affect the use of the payment methods typically associated with bill payments, that is, checks, BAN, or OBBP.This is good news for the validity of our results, as the outcomes of interest seem to be unaffected by whether or not the survey respondent is the household member who makes bill payment decisions.

Few explanatory variables had a significant effect on the use of prepaid cards, but we found that respondents who bought their own prepaid card - as opposed to receiving one as a gift or store credit — were significantly more likely to use it, regardless of their demographic or financial attributes.In addition, black and low-income respondents had higher shares of prepaid card transactions than the rest of the sample, while young consumers used them less than others.

\subsubsection{Other payment instruments}

Our measure of payment use is calculated as shares of the total number of payments conducted with each payment instrument. By construction, the share values are affected by the number of payment instruments adopted.For example, a consumer who has adopted two payment instruments may use each for 50 percent of his transactions, while a consumer with five payment instruments may use each for 20 percent of his transactions, but each of them distributes his transactions equally among his choice set. To prevent the number of adopted instruments from affecting our estimated coefficients, we include a set of dummy variables equal to 1 if the respondent has a given number of other payment instruments adopted. We expect that the higher the number of other choices adopted, the lower the share, and we find this to be the case for cash and checks, but the results are less clear for the remaining payment methods.

As an alternative specification, we included dummy variables for having adopted each payment method specifically, instead of including the set of dummy variables for the number of other payment methods adopted:

$$
U_{i j}=U\left(\overline{R C H A R}_{i j}, D E M_{i}, Y_{i}, \bar{A}_{i j^{\prime}}, M O_{i}, M R_{i}^{-1}\right),
$$

where $\bar{A}_{i j^{\prime}}$ is a set of dummy variables equal to 1 if consumer $i$ adopted payment method $j^{\prime}$ for each $j^{\prime} \neq j$. The results of those regressions are almost identical to the ones shown in the paper. Most of the estimated coefficients on the adoption dummies were negative, indicating that consumers tend to view the various payment methods as substitutes for one another. The results are available from the authors.

Although the survey did not ask about the number of transactions conducted using money orders or traveler's checks, it did ask about the incidence of use of each (that is, if asked whether or not a respondent used these payments, but not how many times the method was used). Traveler's checks were found to be insignificant in the use regressions, but consumers who used money orders had a higher share of cash transactions, and a lower share of BAN and OBBP transactions. Even though one might expect money orders to be a substitute for checks, especially among the unbanked, we did not find a negative effect of money order use on the use of checks, possibly because the vast majority of respondents held a checking account. 


\subsection{Instrumental variable regressions}

Because the payment method characteristics might be endogenous with respect to payment behavior, and thus yield biased coefficients, we employed instrumental variable (IV) estimation. We selected variables in the survey that are most likely exogenous with respect to payment behavior, but that specify certain attributes of consumers, and as such can serve as good instruments for the characteristics. The results of the IV estimation are included in Appendix Table A2, and the instruments we used are listed at the bottom of that table. Unfortunately, the variables were only weakly correlated with the characteristics, and therefore did not make good instruments. As the results in Table A2 indicate, very few explanatory variables were significant in the IV regressions.

\section{Conclusion}

This paper presents the results of an analysis of consumer payment behavior. We improve upon previous literature by employing much improved data and a richer model. Payment characteristics are found to be very important in influencing consumer payment decisions: ease of use, cost and security significantly affect payment use, while setup and record keeping significantly affect payment method adoption. Cost was significant both in adoption and in use of debit cards. Several large banks announced - and later retracted — new fees for debit card use following issuance of the rule on debit card interchange fees, (Note 13)in order to recover their lost revenues from debit card transactions. Our results indicate that consumers are likely to reduce their reliance on debitif these fees were implemented.Future research will include analysis of consumer payment decisions by type of transaction, such as bill payment behavior compared with point-of-sale transactions.

Table A1. Description of Payment Instruments and Characteristics Used in Regressions

\begin{tabular}{cl}
\hline \hline Variable & Description \\
\hline Payment Instruments & \\
\hline Cash & $\begin{array}{l}\text { Coins, Federal Reserve notes, and other paper bills } \\
\text { A draft piece of paper directing a bank or financial institution to pay a specific amount of } \\
\text { money from a demand deposit account, as instructed, to a person or business. }\end{array}$ \\
Credit & $\begin{array}{l}\text { A card that authorizes the cardholder to make a purchase by granting a line of credit that } \\
\text { will be paid back to the card company at a later date, possibly in installments. }\end{array}$ \\
A card that allows the cardholder to make a payment that is deducted directly from a bank \\
account at the time of purchase or bill payment. \\
An electronic payment made directly from a bank account and initiated by a consumer \\
who provides a bank account number and bank routing number to a non-bank third party \\
via the internet. \\
A bill payment made directly from a bank account and initiated by a consumer using the \\
bank's online banking bill payment function on the bank's website. \\
A card that can be used for payments up to the amount of money stored (or loaded) on the \\
card.
\end{tabular}


Table A2. IV Regression Results for Payment Instrument Use

\begin{tabular}{|c|c|c|c|c|c|c|c|c|}
\hline & & Cash & Checks & Credit & Debit & BAN & OBBP & Prepaid \\
\hline \multirow{6}{*}{ Characteristics } & Cost & 0.09 & -0.02 & $0.25^{*}$ & 0.28 & -0.11 & 0.04 & 0.05 \\
\hline & Speed & 0.10 & $0.34^{* * *}$ & $-0.80^{*}$ & 0.27 & 0.08 & 0.02 & 0.04 \\
\hline & Security & 0.02 & 0.13 & -0.15 & $0.28^{*}$ & 0.04 & -0.04 & 0.00 \\
\hline & Control & -0.02 & -0.07 & 0.14 & -0.17 & 0.02 & -0.05 & -0.04 \\
\hline & Records & 0.03 & 0.24 & $0.47^{*}$ & -0.28 & 0.13 & 0.12 & 0.04 \\
\hline & Ease & 0.11 & -0.09 & $0.72^{*}$ & 0.09 & 0.04 & 0.08 & -0.05 \\
\hline \multirow{5}{*}{ Age } & Under 25 & -0.02 & -0.03 & -0.06 & 0.07 & -0.01 & 0.02 & -0.05 \\
\hline & 25 to 34 & -0.04 & 0.04 & -0.01 & 0.02 & 0.01 & $0.04^{* *}$ & 0.00 \\
\hline & 45 to 54 & 0.00 & 0.00 & -0.04 & 0.00 & 0.00 & -0.02 & 0.01 \\
\hline & 55 to 64 & 0.00 & 0.01 & -0.06 & 0.03 & 0.00 & -0.02 & 0.00 \\
\hline & Over 65 & 0.00 & -0.03 & 0.00 & -0.01 & 0.01 & -0.04 & -0.01 \\
\hline \multirow{4}{*}{ Education } & Less Than High School & 0.08 & -0.04 & $-0.46^{* *}$ & 0.15 & -0.14 & -0.17 & \\
\hline & High School & 0.01 & 0.00 & -0.04 & 0.03 & 0.02 & -0.02 & 0.01 \\
\hline & Some College & 0.02 & 0.00 & -0.04 & 0.05 & 0.01 & 0.00 & 0.00 \\
\hline & Graduate School & 0.01 & -0.02 & 0.01 & -0.05 & 0.00 & -0.01 & 0.01 \\
\hline \multirow{4}{*}{ Marital Status } & Separated & 0.03 & 0.02 & -0.01 & -0.01 & 0.02 & -0.01 & 0.01 \\
\hline & Widowed & 0.04 & 0.02 & -0.05 & 0.05 & -0.02 & -0.03 & 0.02 \\
\hline & Single & 0.02 & -0.04 & -0.02 & -0.02 & 0.02 & -0.01 & 0.00 \\
\hline & Household Size & 0.00 & 0.00 & $-0.03^{*}$ & 0.01 & $0.01^{* *}$ & 0.00 & 0.00 \\
\hline Ethnicity & Latino & 0.03 & 0.00 & 0.03 & -0.10 & 0.04 & 0.03 & 0.01 \\
\hline \multirow{3}{*}{ Race } & Black & -0.01 & 0.01 & -0.04 & -0.02 & -0.01 & -0.03 & 0.00 \\
\hline & Asian & $-0.09^{*}$ & -0.02 & 0.05 & -0.12 & $0.10^{*}$ & 0.04 & 0.01 \\
\hline & American Indian/Other & -0.11 & 0.06 & -0.02 & 0.02 & 0.01 & 0.06 & -0.02 \\
\hline Gender & Male & $0.06^{* * *}$ & -0.01 & -0.03 & $-0.08^{* *}$ & 0.02 & -0.01 & 0.02 \\
\hline \multirow{6}{*}{ Income } & Under $\$ 25,000$ & $0.07^{* *}$ & -0.01 & $-0.11^{*}$ & 0.01 & -0.03 & -0.03 & 0.03 \\
\hline & $\$ 25,000$ to $\$ 49,000$ & $0.04^{* *}$ & 0.02 & $-0.07^{*}$ & -0.01 & -0.02 & -0.01 & -0.03 \\
\hline & $\$ 75,000$ to $\$ 99,000$ & 0.00 & -0.01 & -0.01 & -0.02 & -0.01 & 0.00 & -0.03 \\
\hline & Over $\$ 100,000$ & -0.02 & 0.01 & 0.07 & -0.05 & -0.01 & 0.04 & -0.02 \\
\hline & Not Highest Income in & & & & & & & \\
\hline & Household & 0.03 & -0.01 & -0.06 & 0.00 & 0.00 & -0.03 & 0.03 \\
\hline
\end{tabular}

Continued on next page 
Table A2. IV Regression Results for Payment Instrument Use continued

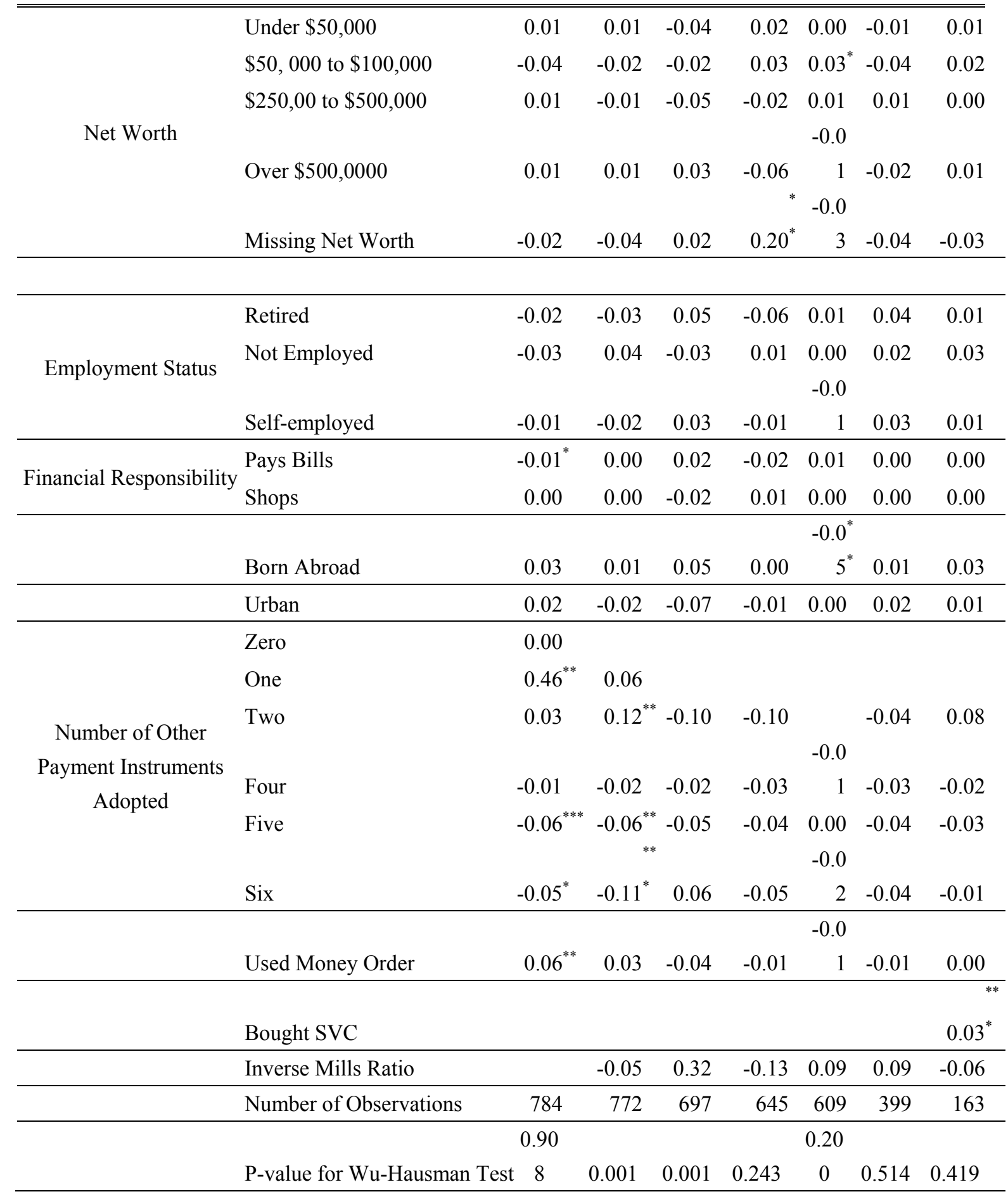

Source: 2008 Survey of Consumer Payment Choice

${ }^{*} \mathrm{p}<0.1,{ }^{* *} \mathrm{p}<0.05,{ }^{* * *} \mathrm{p}<0.01$

Instruments: Self-checkout, ID Theft, Telephone Privacy, Entering Info Online, Paperless Statements, Interest in Interview, Willing to Do Interview on Phone, Check Conversion, Taxes, Coupons/Discounts, Religion 


\section{References}

Arango, C. \& V. Taylor. (2009). "The Role of Convenience and Risk in Consumers' Means of Payment." Bank of Canada Discussion Paper No. 2009-8.

Bertaut, C. C. \& M. Haliassos. (2005). "Credit Cards: Facts and Theories." The Economics of Consumer Credit. G. Bertola, R. Disney and C. Grant, eds. MIT Press, April.

Bolt, W., D. Humphrey, \& R. Uittenbogaard. (2008). "The Effect of Transaction Pricing on the Adoption of Electronic Payments: A Cross-Country Comparison," International Journal of Central Banking. 4, March: 89-123.

Borzekowski, R. \& E. Kiser. (2007). "The Choice at the Checkout: Quantifying Demand across Payment Instruments." International Journal of Industrial Organization. 26(4): 889-902. http://dx.doi.org/10.1016/j.ijindorg.2007.07.006

Borzekowski, R., E. Kiser \& S. Ahmed. (2008). "Consumers' Use of Debit Cards: Patterns, Preferences, and Price Response." Journal of Money, Credit and Banking. 40(1): 149-172. http://dx.doi.org/10.1111/j.1538-4616.2008.00107.x

Bounie, D. \& A. François. (2006). "Cash, Check or Bank Card? The Effects of Transaction Characteristics on the Use of Payment Instruments.” Télécom Paris Economics and Social Sciences Working Paper No. ESS-06-05.

Ching, A. \& F. Hayashi. (2010). "Payment Card Rewards Programs and Consumer Payment Choice." Journal of Banking and Finance. 34(8): 1773-1787. http://dx.doi.org/10.1016/j.jbankfin.2010.03.015

Foster, K., E. Meijer, S. Schuh, \& M. A. Zabek. (2009). “The 2008 Survey of Consumer Payment Choice.” Federal Reserve Bank of Boston Public Policy Discussion Paper No. 09-10.

Hogarth, J. M., C. E. Anguelov, \& J. Lee. (2005). "Who Has a Bank Account? Exploring Changes Over Time, 1989-2001." Journal of Family and Economic Issues. 26(1):7-30, Spring. http://dx.doi.org/10.1007/s10834-004-1410-6

Klee, E. (2006). "Families' Use of Payment Instruments during a Decade of Change in the U.S. Payment System." Finance and Economics Discussion Paper No. 2006-01, February.

Klee, E. (2008). "How People Pay: Evidence from Grocery Store Data." Journal of Monetary Economics. 55(3): 526-541. http://dx.doi.org/10.1016/j.jmoneco.2008.01.009

Mann, R. J. (2011). “Adopting, Using, and Discarding Paper and Electronic Payment Instruments: Variation by Age and Race.” Federal Reserve Bank of Boston Public Policy Discussion Paper No. 11-2.

Mester, L. J. (2003). "Changes in the Use of Electronic Means of Payment: 1995-2001.” Federal Reserve Bank of Philadelphia. Business Review. Q3:18-20.

Mester, L. J. (2006). "Changes in the Use of Electronic Means of Payment: 1995-2004. "Federal Reserve Bank of Philadelphia. Business Review. Q2: 26-30.

Newey, W.K., J.L. Powell, \& J.R. Walker. (1990). "Semiparametric Estimation of Selection Models: Some Empirical Results." American Economic Review, Papers and Proceedings80: 324-328.

Schuh, S.\&J.Stavins. (2010). "Why Are (Some) Consumers (Finally) Writing FewerChecks? The Role of Payment Characteristics." Journal of Banking and Finance. 34: 1745-1758, August. http://dx.doi.org/10.1016/j.jbankfin.2009.09.018

Stavins, J. (2001). "Effect of Consumer Characteristics on the Use of Payment Instruments." Federal Reserve Bank of Boston. New England Economic Review. 3Q: 19-31.

Zinman, J. (2009). “Debit or Credit?” Journal of Banking \& Finance. 33:358-366. http://dx.doi.org/10.1016/j.jbankfin.2008.08.009 


\section{Notes}

Note 1. http://www.federalreserve.gov/newsevents/press/bcreg/20110629a.htm

Note 2. Some large banks announced an increase in debit card fees following announcement of the new interchange fee policy, although the fees were later retracted.

Note 3. See Foster et al. (2009) for more detailed information on the 2008 SCPC.

Note 4. Although we collect data on adoption and use of nine payment instruments, we do not ask about respondents' perceived characteristics of money orders or traveler's checks. Therefore those two payment instruments are excluded from the regressions.

Note 5. See Schuh and Stavins (2010).

Note 6. These numbers are available from the authors.

Note 7. The results are available from the authors.

Note 8. We explored estimating the model using semiparametric methods. Newey, Powell, and Walker (1990) compare the Heckman two-step estimation to semiparametric estimation methods, and find that semiparametric estimators do not give significantly different results from the two-step estimator. Therefore, we apply the Heckman two-step method here.

Note 9.For example, Klee (2006), Mester (2003, 2006), Stavins (2001), and Zinman (2009).

Note 10. In addition to the Heckman method shown here, we estimated the number of payment methods adopted using OLS and discrete choice models, namely ordered logit and negative binomial. OLS and ordered logit yield very similar results to the ones reported in the paper.

Note 11. Because the survey did not ask separately for online banking characteristics, we used the characteristics reported for BAN in the OBBP regressions.

Note 12. We estimated the second stage (use) regressions under alternative assumptions. In one specification, we changed the definition of adopters to those consumers who had non-zero incidence of use, and nonadopters were those who either did not adopt or did not use a given payment instrument. Defining adoption in that way yielded qualitatively similar results to the results reported here.

Note 13. http://www.federalreserve.gov/newsevents/press/bcreg/20110629a.htm 